\title{
Senam Ibu Hamil dan Karakteristik Ibu Membantu Meningkatkan Persalinan
}

\author{
Indri Wahyuni $^{1}$, Justina Purwarini ${ }^{2}$ \\ ${ }^{1,2}$ Departemen Keperawatan Maternitas, Sekolah Tinggi Ilmu Kesehatan Sint Carolus \\ Email : indriwahyuni1589@gmail.com; justinearini@gmail.com
}

\begin{abstract}
Abstrak
Pendahuluan: Salah satu faktor yang dapat mempengaruhi proses persalinan adalah power yang dapat dilatih dengan mengikuti senam ha mil, karena memberikan dampak terhadap ibu saat bersalin.

Tujuan: Untuk mengetahui hubungan karakteristik ibu dan senam hamil dengan tipe persalinan.

Metode: Penelitian ini merupakan penelitian deskriptif korelatif dengan penelitian cross sectional, serta menggunakan desain kuantitatif non eksperimental.

Hasil: Penelitian menunjukkan ada hubungan bermakna antara karakteristik responden (Usia, pendidikan, pekerjaan, paritas) serta senam hamil (p-value $=0,000)$ dengan tipe persalinan.

Kesimpulan: Senam hamil dapat membantu persalinan sehingga ibu dapat melahirkan tanpa kesulitan serta menjaga ibu dan bayi sehat setelah melahirkan. Senam hamil sangat diperlukan oleh ibu terutama pada primigravida untuk mempersiapkan fisik dan mental ibu dalam menghadapi persalinan.
\end{abstract}

Kata Kunci: karakteristik, ibu hamil, senam hamil, tipe persalinan

\section{Pendahuluan}

Salah satu indikator kesehatan suatu bangsa ditentukan oleh derajat kesehatan ibu dan anak, Angka Kematian Ibu (AKI) merupakan indikator yang digunakan untuk mengukur status kesehatan ibu pada suatu wilayah. Menurut World Health Organization (WHO), kematian ibu adalah kematian selama kehamilan atau dalam periode 42 hari setelah persalinan. Menurut Word Health Organization (WHO) angka kematian ibu tahun 2016 sangat

\begin{abstract}
Introduction: One of the factors that can influence the delivery process is power, that can be trained by following the exercise pregnancy, because it has an impact on the mother during childbirth.

Objective: The purpose of this research is to know the relationship between the characteristic and pregnant exercise with type of delivery.

Method: This research is a descriptive correlative research with cross-sectional research and using no experimental quantitative design.

Results: The result shows that there is a significant correlation between respondent characteristic (age, education, job, parity) and pregnancy exercise (p-value $=0,000)$ and type of delivery.

Conclusion: Exercise pregnancy can help delivery so that mother can give birth without difficulty and keep mother and baby healthy after giving birth. Pregnancy exercise is needed by mothers especially in primigravida to prepare physically and mentally mother in facing childbirth.
\end{abstract}

Keywords: characteristic, pregnant women, exercise pregnancy, type of delivery

tinggi sekitar 830 wanita meninggal karena komplikasi kehamilan atau persalinan di seluruh dunia setiap hari. Pada tahun 2015 jumlah total kematian ibu diperkirakan mencapai 303.000 kematian di seluruh dunia.

Berdasarkan Survei Demografi dan Kesehatan Indonesia (SDKI) Tahun 2012, AKI yang berkaitan dengan kehamilan, persalinan, dan nifas sebesar 359 per 100.000 kelahiran hidup. Angka ini masih jauh dari target 
MGDS yang harus dicapai pada tahun 2015. Saat ini angka kematian maternal dan perinatal di Indonesia masih cukup tinggi. Target AKI di Indonesia pada tahun 2015 adalah 102 kematian per 100.000 kelahiran hidup. Penyebab langsung kematian ibu adalah perdarahan $30,3 \%$, eklampsi $27,1 \%$, infeksi $7,3 \%$, partus lama $0,0 \%$, abortus $0,0 \%$ dan lain-lain $40,8 \%{ }^{2}$

Proses persalinan pada ibu bersalin normal berlangsung dalam waktu kurang dari 24 jam, dimana terbagi dalam empat kala. Kala I pada fase laten berlangsung selama delapan jam dan fase aktif berlangsung selama tujuh jam. Persalinan kala II biasanya berlangsung dua jam pada primi dan satu jam pada multigravida, kala III berlangsung kurang dari 30 menit sedangkan kala IV dimulai dari saat lahirnya plasenta sampai dua jam pertama postpartum.

Lamanya proses persalinan dapat dipengaruhi oleh tiga hal yaitu tenaga, jalan lahir dan janin. Salah satu yang dapat di kendalikan dalam proses persalinan adalah tenaga atau power, yang dapat dilakukan dengan senam hamil secara teratur. Senam selama dalam kehamilan memberikan efek yang positif terhadap pembukaan serviks dan aktivitas uterus yang yang terkoordinasi saat proses persalinan, serta dapat ditemukan persalinan yang lebih awal dan lama persalinan yang lebih singkat dibandingkan ibu yang tidak melakukan senam hamil. Senam hamil dapat membantu persalinan sehingga ibu dapat melahirkan tanpa kesulitan, serta menjaga ibu dan bayi sehat setekah melahirkan. ${ }^{4}$

Ibu hamil belum tahu sepenuhnya tentang senam hamil di karenakan para ibu hamil kurang mengetahui apa itu senam hamil, tujuan dan manfaat senam hamil hal ini dikarenakan ibu kurang informasi sepenuhmya tentang senam hamil. Pengetahuan ibu hamil tentang senam hamil dapat menurunkan kecemasan ibu dalam menghadapi persalinan. Hal ini di dukung dengan adanya penelitian pengetahuan ibu hamil tentang senam hamil dengan responden 90 orang dengan hasil $13,33 \%$ berpengetahuan baik, $40,00 \%$ berpengetahuan cukup, $46,7 \%$ memiliki tingkat pengetahuan kurang.

Hasil Penelitian yang dilakukan Mintarsih (2015) tentang pengaruh senam hamil terhadap lama persalinan kala I pada ibu post-partum spontan primipara memiliki hasil ada pengaruh senam hamil terhadap lama persalinan kala I pada ibu post-partum primipara ( $p$ value $=0,013<0,05) .{ }^{6}$ Hal tersebut selaras dengan penelitian Rahmawati, et al (2016) yang menyatakan bahwa ada hubungan senam hamil dengan lamanya proses persalinan pada ibu bersalin di Wilayah Kerja Puskesmas Bayat Klaten ( $p$-value: $0,012<0,05){ }^{7}$ Demikian juga dalam penelitian Aulia \& Hindun (2010) yang mengatakan ada pengaruh senam hamil terhadap proses persalinan normal dengan nilai (p-value: 0,014). ${ }^{4}$ Suryati (2012) juga menyebutkan bahwa tingkat persalinan section caesar di Indonesia 15,3\% dengan sampel 20,591 ibu yang melahirkan dalam waktu kurun 5 tahun terakhir di 33 provinsi dengan (p-value $5 \%$ ) dengan gambaran ibu yang di operasi section caesar 65,5 $\%$ bertempat tinggal di kota, $50,25 \%$ pendidikan ibu lulus SLTP, 38\% adalah anak pertama/ primipara. ${ }^{8}$ Berdasarkan data diatas dan masih sedikitnya penelitian tentang senam hamil dan belum diketahuinya hubungan karakteristik ibu dan senam hamil dengan tipe persalinan, maka peneliti tertarik untuk melakukan penelitian tentang hal tersebut.

\section{Metode}

Metode penelitian yang digunakan dalam peneltitian adalah deskriptif korelasi, dimana peneliti menilai hubungan antara variabel independen dan variabel dependen dengan cross sectional, melalui desain kuantitatif non eksperimental. Data variabel dependen dan independen di ambil dalam waktu yang bersamaan.Variabel independen pada penelitian adalah yaitu usia, pendidikan, pekerjaan, paritas dan faktor lain adalah senam hamil, sedangkan variabel dependen adalah tipe persalinan yang dikelompokan persalinan spontan dan persalinan dengan section caesaria.

Populasi dalam penelitian ini adalah semua ibu yang melahirkan di RS X yaitu sebanyak 425 dalam 4 bulan terakhir dan menggunakan teknik total sampling. Teknik total sampling adalah teknik penentuan sample dengan mengambil seluruh anggota populasi sebagai responden. Dengan demikian maka peneliti mengambil total sample dari seluruh pasien yang melahirkan secara postpartum spontan dan section caesar di RS X menggunakan data sekunder dari rekam medis. Kriteria inklusi yang di ambil adalah data ibu 
yang melahirkan baik spontan maupun section caesar yang terdaftar sebagai pasien tetap di RS X. Alat pengumpul data dalam penelitian ini menggunakan form lembar observasi operasional yang berisi karakteristik ibu peser-

\section{Hasil}

Hasil penelitian dijabarkan sebagai berikut ini ta senam hamil dan tipe persalinan dengan kriteria responden usia, pendidikan, paritas, pekerjaan, dan ikut senam hamil dan tipe persalinan dirumah sakit

$\mathrm{X}$.

Gambar 1. Distribusi frekuensi karakteristik responden berdasarkan usia, pendidikan, pekerjaan, paritas, peserta senam dan tipe persalinan di Bekasi

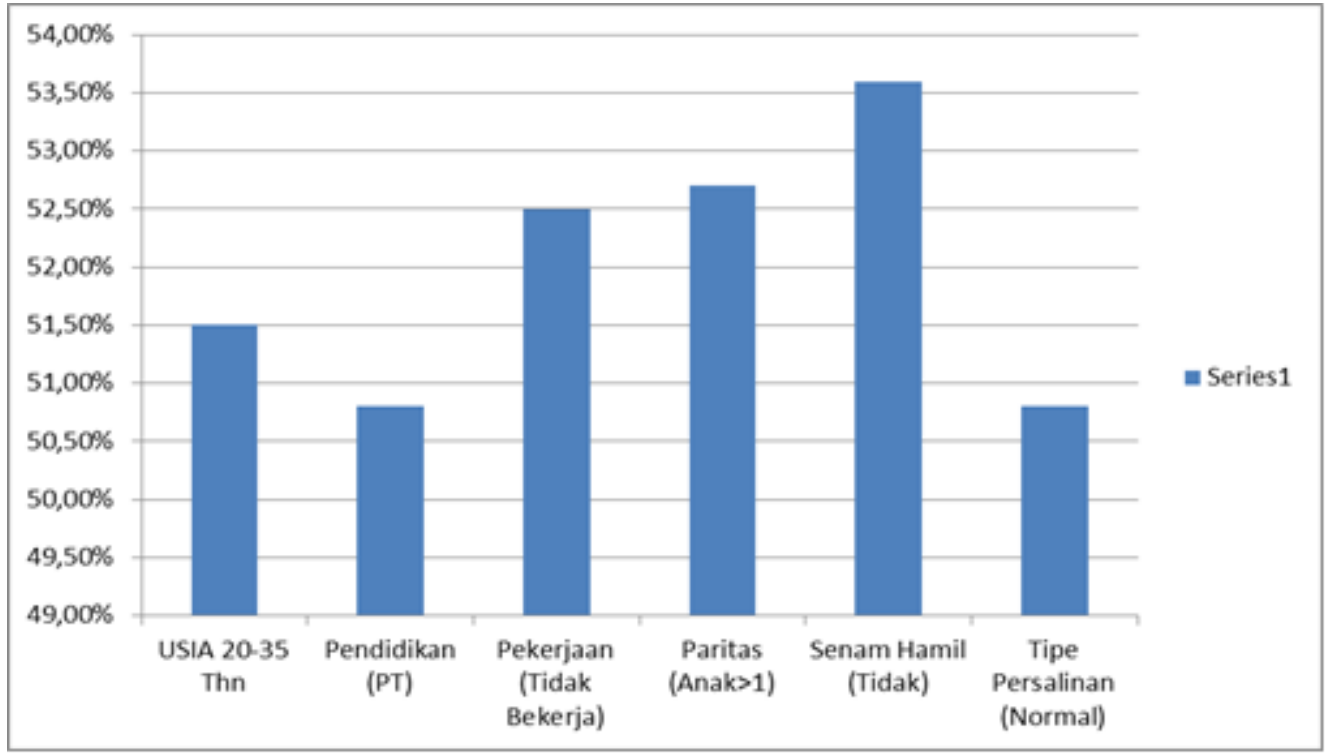

Berdasarkan grafik diatas terlihat bahwa sebagian besar responden berada pada rentang usia 20-35 tahun (51,5\%) dimana ini adalah usia produktif, sedangkan usia $<20$ tahun dan $>35$ tahun sebanyak $48,5 \%$. Bila dilihat berdasarkan tingkat pendidikan sebagian besar responden berpendidikan tinggi $(50,8 \%)$. Distribusi pekerjaan sebagian besar responden tidak bekerja $(52,5 \%)$, mayoritas responden $(52,7 \%)$ memiliki paritas multipara atau memiliki anak $>1$. Grafik juga memperlihatkan bahwa seba- gian besar responden selama hamil tidak mengikuti kegiatan senam hamil $(53,6 \%)$ dan sisanya $(46,4 \%)$ mengikuti senam hamil yang diadakan oleh rumah sakit tempat mereka secara rutin memeriksakan kehamilannya. Karakteristik responden berdasarkan tipe persalinan yang paling besar adalah persalinan normal dengan responden sebesar 50,8\% (216 orang) dan sisanya 49,2\% merupakan persalinan section caesar.

Tabel 1. Hubungan Karakteristik ibu dan senam hamil dengan tipe persalinan di Bekasi

\begin{tabular}{|c|c|c|c|c|c|c|c|c|}
\hline \multirow[t]{3}{*}{ Karakteristik } & \multirow[t]{3}{*}{ Kelompok } & \multicolumn{4}{|c|}{ Tipe Persalinan } & \multirow{2}{*}{\multicolumn{2}{|c|}{ Total }} & \multirow[t]{3}{*}{$P$ Value } \\
\hline & & \multicolumn{2}{|c|}{ Normal } & \multicolumn{2}{|c|}{ Sectio Caesarea } & & & \\
\hline & & n & $\%$ & n & $\%$ & $\mathbf{n}$ & $\%$ & \\
\hline \multirow[b]{2}{*}{ Usia } & 20-35 Tahun & 195 & 89,0 & 24 & 11,0 & 219 & 100 & \multirow[t]{2}{*}{0,000} \\
\hline & $\begin{array}{l}<20 \text { dan } \\
>35 \text { Tahun }\end{array}$ & 21 & 10,2 & 185 & 99,8 & 206 & 100 & \\
\hline Pendidikan & SMA & 209 & 100 & 0 & 0,0 & 209 & 100 & 0,000 \\
\hline
\end{tabular}




\begin{tabular}{|c|c|c|c|c|c|c|c|c|}
\hline & $\mathrm{PT}$ & 7 & 3,2 & 209 & 96,8 & 216 & 100 & \\
\hline \multirow[t]{2}{*}{ Pekerjaan } & Bekerja & 188 & 93,1 & 14 & 6,9 & 202 & 100 & \multirow[t]{2}{*}{0,000} \\
\hline & $\begin{array}{l}\text { Tidak } \\
\text { bekerja }\end{array}$ & 28 & 12,6 & 195 & 99,8 & 223 & 100 & \\
\hline \multirow[t]{2}{*}{ Paritas } & Anak 1 & 183 & 91,0 & 18 & 9,0 & 201 & 100 & \multirow[t]{2}{*}{0,000} \\
\hline & Anak>1 & 33 & 14,7 & 191 & 85,3 & 224 & 100 & \\
\hline \multirow[t]{2}{*}{ Senam Hamil } & $\mathrm{Ya}$ & 197 & 100 & 0 & 0,0 & 197 & 100 & \multirow[t]{2}{*}{0,000} \\
\hline & Tidak & 19 & 8,3 & 209 & 91,7 & 228 & 100 & \\
\hline
\end{tabular}

Tabel 1. Memperlihatkan hubungan karakteristik responden, senam hamil dengan tipe persalinan yang dijalani oleh responden. Berdasarkan usia, mayoritas responden yang memiliki usia produktif ( $20-35$ tahun) dan melahirkan dengan normal atau spontan sebanyak 89\% (195 responden). Hasil uji hitung dengan chi-square memperlihatkan bahwa ada hubungan bermakna antara usia dengan jenis persalinan $(p$ value $=0,00<0,05)$.

Data juga menunjukkan bahwa semua responden yang berpendidikan SMA ternyata melahirkan secara normal atau spontan sebesar $100 \%$. Hasil $p$ value juga menunjukkan bahwa ada hubungan bermakna antara pendidikan dengan tipe persalinan $(p=0,00<0,05)$. Untuk karakteristik pekerjaan, responden yang tidak bekerja dan melahirkan secara section caesarea sebesar 99, 8\% (195 responden) dengan $p$ val$u e=0,00(p<0,05)$. Hal ini berarti bahwa ada hubungan bermakna antara pekerjaan dengan tipe persalinan.

Karakteristik lain yang diteliti pada responden adalah paritas. Responden yang memiliki anak lebih dari 1 dan menjalani tipe persalinan seksio Caesarea sebanyak 85, 3\% (191 responden). Hasil uji hitung chi-square memperlihatkan $p$ value $=0,00$ yang berarti bahwa ada hubungan bermakna antara paritas dengan tipe persalinan. Berdasarkan ikut serta dalam program senam hamil, responden yang mengikuti senam hamil, semua melahirkan secara spontan (100\%) dengan jumlah responden 197 orang. Uji statistic memperlihatkan bahwa ada hubungan bermakna antara senam hamil dengan tipe persalinan $(p$ value $=0,00)$.

\section{Pembahasan}

Pada penelitian ini sebagian besar responden berada pada rentang usia 20-35 tahun. Penelitian BKKBN (2012) menyatakan usia ideal wanita untuk hamil dan melahirkan adalah usia 20-35 tahun, dimana pada usia tersebut seorang wanita berada pada masa kesuburan yang tinggi dan secara fisik dan psikologis sudah siap untuk hamil. Menurut tingkat pendidikan, sebagian besar responden berpendidikan tinggi yaitu 216 responden. ${ }^{9}$ Notoatmodjo (2012) menyatakan bahwa umumnya semakin tinggi pendidikan seseorang semakin mudah untuk mendapatkan informasi. ${ }^{10}$

Berdasarkan pekerjaannya, responden yang tidak bekerja sebanyak 52, 5\%, sedangkan sisanya 47, 5\% bekerja. Seseorang yang bekerja mempunyai kesempatan yang lebih banyak untuk berinteraksi dengan orang lain, sehingga lebih banyak peluang untuk mendapatkan informasi seputar keadaan kesehatannya. Karakteristik responden berdasarkan paritas, sebagian besar responden memiliki anak lebih dari 1 (multipara) sebanyak 52, 7\%. Berdasarkan keikuitsertaan dalam senam hamil, sebagian besar responden tidak mengikuti kegiatan senam hamil (228 responden) dengan prosentase 53,6\%. Berdasarkan tipe persalinan yang dijalankan, sebagian besar memilih persalian normal $(50,8 \%)$ dengan responden 216 orang.

Penelitian ini juga memperlihatkan bahwa ada hubungan bermakna antara usia ibu hamil dan tipe persalinan. Hal ini didukung dengan penelitian Aulia \& Hindun (2010) yang menyatakan usia 20-35 tahun merupakan usia yang ideal karena uterus dan bagian tubuh lainnya sudah siap untuk hamil, sedangkan usia kurang dari 20 tahun dan lebih dari 35 tahun adalah usia yang beresiko karena bila di bawah 20 tahun uterus belum siap menerima kehamilan dan bila diatas 35 tahun sangat beresiko untuk persalinan patologis sebagai indikasi untuk melahirkan secara sectio caesar.

Persalinan section caesar sebagian besar pada usia kurang dari 20 tahun dan lebih dari 35 tahun. Detiana (2010) mengatakan bahwa pada usia kurang dari 20 tahun berpengaruh pada kematangan fisik dan mental ibu dalam menghadapi kehamilan dan persalinan. Rahim dan panggul ibu belum tumbuh matang mencapai ukuran dewasa, selain itu 
juga berpengaruh terhadap ketrampilan ibu dalam merawat diri dan bayinya, sehingga pada usia ini ibu cenderung mengalami persalinan sectio caesar walaupun tanpa indikasi dengan pertimbangan kekwatiran ibu pada dirinya dalam menghadapi proses persalinan dan keselamatan janin. Pada usia lebih dari 35 tahun, sebagian besar responden telah memiliki lebih dari 1 anak, atau riwayat persalinan secara sectio caesar, sehingga pada persalinan saat ini responden atau kondisi responden yang mengharuskan untuk dilakukan persalinan secara section caesar. ${ }^{13}$

Selanjutnya, hasil uji chi-square juga menunjukkan ada hubungan bermakna antara pendidikan dan tipe persalinan ( $p$ value $=$ $0,000<0$, 05). Notoatmodjo (2012) menyatakan bahwa umumnya semakin tinggi pendidikan seseorang semakin mudah untuk mendapatkan informasi. ${ }^{10}$ Semakin tinggi pendidikan seseorang maka semakin cepat memahami tentang resiko persalinan yang akan di hadapi. Pada penelitian ini ditemukan adanya hubungan yang bermakna antara pendidikan dengan tipe persalinan. ${ }^{12}$ Peneliti berasumsi bahwa dalam penelitian ini adalah semakin tinggi tingkat pendidikan seseorang maka semakin mudah baginya untuk mengerti dan memahami resiko dalam persalinan, sehingga ibu yang berpendidikan tinggi cenderung memilih persalinan sectio caesar. Ambang nyeri tinggi yang di miliki ibu yang berpendidikan tinggi memudahkan ibu untuk memutuskan persalianan sectio caesar di tambah pengetahuan tentang resiko dalam persalinan. ${ }^{18}$

Penelitian ini juga memperlihatkan bahwa ada hubungan bermakna antara pekerjaan dan tipe persalinan. Penelitian lain yang mendukung hal tersebut diungkapkan oleh Khodijah, et al (2014) yang menyatakan bahwa ibu bekerja (PNS) memiliki angka persalinan section caesar yang rendah. ${ }^{11}$ Namun, penmelitian lain yang berbeda pendapat adalah penelitian Muhammad, et al (2014) yang menyatakan ibu yang tidak bekerja yang mengalami persalinan section caesar paling sedikit 17 responden $(19,5 \%){ }^{12}$ Pada penelitian ini ibu bekerja banyak mendapatkan informasi medis, tenaga penyuluhan dan teman rekan kerja yang dapat mempengaruhi ibu pekerja untuk memilih persalinan yang akan di lakukan. Ibu bekerja juga justru lebih memperhatikan kehamilan dan persalinan, sehingga ibu bekerja memilih persalinan normal karena cepat pemulihannya dan cepat beraktivitas seperti biasa. Ibu tidak bekerja akan berisko lebih tinggi untuk untuk melahirkan secara sectio caesar karena kurangnya informasi dan aktivitas social dalam suatu komunitas yang dapat mempengaruhi ibu dalam memilih persalinan yang nantinya akan dilakukan.

Karakteristik lain yang diteliti adalah paritas. Penelitian memperlihatkan bahwa ada hubungan bermakna antara paritas dan tipe persalinan diperlihatkan dengan hasil uji chisquare $P$-Value $=0,000$ ( $P$-Value $<0.05)$. Hal ini tidak sejalan dengan penelitian Muhammad, et al (2014) dimana dalam risetnya menyatakan bahwa ibu yang memiliki anak lebih dari 1 (multipara) memiliki resiko rendah untuk bersalin section Caesar. ${ }^{12}$ Pada ibu primipara atau ibu hamil anak pertama, belum memiliki pengalaman dalam persalinan, sedangkan ibu multipara sudah mempunyai pengalaman sebelumnya tentang persalinan. ${ }^{15} \mathrm{Hal}$ ini menyebabkan banyak ibu primipara lebih semangat untuk memilih persalinan normal karena ingin melahirkan dengan proses yang semestinya atau normal. KOndisi yang berbeda pada ibu multipara jika anak pertama melahirkan secara section caesar dan jarak melahirkan anak pertama dengan anak kedua dekat, maka kelahiran anak kedua kemungkinan akan section caesar lagi. ${ }^{16}$ Hal ini sesuai dengan hasil dari penelitian bahwa responden yang memiliki anak>1 memperlihatkan prosentase yang lebih tinggi dibanding persalinan normal.

Variable terakhir yang terlihat pada table adalah adanya hubungan bermakna antara senam hamil dan tipe persalinan dengan $P$ Value $=0,000(P$-Value $<0.05)$. Senam hamil merupakan suatu usaha untuk mencapai kondisi yang optimal dalam mempersiapkan proses persalinan dengan cara di rancang latihan- latihan serta memperbaiki keseimbangan fisik bagi ibu hamil. ${ }^{17} \mathrm{Hal}$ ini di dukung dengan penelitian Aulia \& Hindun (2010) yang melakukan penelitian melalui case control, dimana dari hasil penelitian didapatkan $p$ value $0,014(p<0,05)$ artinya ada pengaruh senam hamil terhadap persalinan normal. ${ }^{4}$ Peneliti memiliki asumsi bahwa ada hubungan antara senam hamil dan tipe persalinan karena seorang ibu yang akan melahirkan normal telah mempersiapkan diri seacara fisik dan men- 
tal dengan mengikuti senam hamil melatih fisik sehingga dapat memperoleh kekuatan, tonus otot yang baik dan teknik pernapasan yang baik. Ibu yang melakukan senam hamil dan sering olah raga selama hamil, dalam proses persalinannya akan berlangsung secara cepat serta mengalami penyembuhan segera dari pada ibu yang tidak berolah raga selama hamil. ${ }^{14}$

Dalam penelitian ini, karena data sekunder yang digunakan sehingga semua data yang diinginkan dapat diperoleh melalui rekam medik dengan sebelumnya meminta ijin pada institusi terkait

\section{Kesimpulan}

Berdasarkan penelitian mengenai hubungan karakteristik ibu dan senam hamil dengan tipe persalinan dapat disimpulkan gambaran karakteristik ibu, dilihat dari segi usia bahwa sebagian besar ibu berada pada usia 20-35 tahun $(51,5 \%)$, dengan berpendidikan tinggi sebanyak 50,2\%. Berdasarkan pekerjaan, sebagian besar responden tidak bekerja $(52,7 \%)$ dan memiliki paritas lebih dari 1 (multipara) 52, 7\%. Berdasarkan keikutsertaan program senam hamil, sebagian besar responden $(53,6 \%)$ tidak mengikuti senam hamil dan $50,8 \%$ responden melakukan persalinan secara normal atau spontan.

Tipe persalinan di Bekasi memiliki hubungan yang bermakna dengan usia, pendidikan, pekerjaan, paritas serta keikutsertaan ibu dalam pelaksanaan senam hamil. Hasil uji chi-square memperlihatkan nilai $p$-value $=$ $0,000(p<0,05)$ untuk semua variable independen (Usia, tingkat pengigikan, pekerjaan, paritas dan senam hamil).

\section{Daftar pustaka}

1. World Health Organization, UNICEF. Trends in maternal Mortality: 1990-2015: Estimates from WHO, UNICEF, UNFPA, World Bank Group and the United Nations Population Division.

2. Depkes RI. Profil Kesehatan Indonesia 2012. Jakarta: Departemen Kesehatan Republik Indonesia. 2013.

3. Saifuddin AB. Buku acuan nasional pelayanan kesehatan maternal dan neonatal. Jakarta: Yayasan Bina Pustaka Sarwono Prawirohardjo. 2006;100:111-2.

4. Aulia H, Hindun S. Pengaruh Senam Hamil Terhadap Proses Persalinan Normal Di Klinik YK Madira Palembang. Jurnal
Kedokteran dan Kesehatan Fakultas Kedokteran UNSRI. 2010(1):2782-7.

5. Suratiah, dkk. Pengetahuan Ibu Hamil tentang Senam Hamil terhadap Insidensi persalinan Lama di Kelurahan Bale Ageng. Bali: Politekhnik Kesehatan Denpasar. 2013.

6. Mintarsih S. Pengaruh Senam Hamil terhadap Lama Persalinan Kala I pada Ibu Post Patum Spontan Primipara. Jurnal Keperawatan GSH. 2015; 4(2).

7. Rahmawati Na, Lestari S. Hubungan Senam Hamil Terhadap Lamanya Proses Persalinan Pada Ibu Bersalin Di Wilayah Kerja Puskesmas Bayat Klaten. Involusi Jurnal Ilmu Kebidanan. 2016 Jul 20; 6(11).

8. Suryati T. Analisis Lanjut Data Riskesdas (2010) Presentase Operasi Caesarea di Indonesia Melebihi Standard Maksimal, Apakah Sesuai Indikasi Medis. Output Filee-Journal Badan Penelitian dan Pengembangan. 2012.

9. BKKBN. Profi 1 Hasil Pendataan Keluarga. 2012.

10. Notoatmodjo S. Metodologi penelitian kesehatan (Cetakan VI). Jakarta: Penerbit PT. Rineka Cipta. 2012.

11. Khodijah D, Siburian YR, Sinaga R. Hubungan Karakteristik Ibu Dengan Sectio Caesarea Di Rumah Sakit TK IV 01.07. 001 KESDAM I/BB Pematangsiantar. Jurnal Ilmiah PANNMED (Pharmacist, Analyst, Nurse, Nutrition, Midwivery, Environment, Dentist). 2014; 9(1):84-9.

12. Muhammad R, Rahayuningsih FB, Yulian V. Karakteristik ibu yang mengalami persalinan dengan sectio caesarea di rumah sakit umum daerah Moewardi Surakarta tahun 2014 (Doctoral dissertation, Universitas Muhammadiyah Surakarta).

13. Detiana P. Hamil Aman dan Nyaman di Atas 30 Tahun. Media Pressindo; 2010.

14. Yosefa F, Hasneli Y. Efektifitas Senam Hamil Terhadap Penurunan Nyeri Punggung pada Ibu Hamil (Doctoral dissertation, Riau University); 2014.

15. Utami RN. Perbedaan Efektivitas Lama Pemberian Rose Effleurage terhadap Intensitas Nyeri Kala I Fase Aktif pada Persalinan Normal Primigravida di Kota Semarang Tahun 2013. Jurnal kebidanan. 2013;2(4):20-30.

16. Andriani D. Faktor-Faktor Yang Mempengaruhi Tindakan Seksio Sesarea di Rumah Sakit Umum Daerah Kabupaten Dompu Tahun 2010. Jakarta: Fakultas Kesehatan Masyarakat Universitas Indonesia. 2012. 
17. Prameswary, Ayundya, and Fazar Kumaladewi. "Hubungan Inisiasi Menyusu Dini (IMD), Mobilisasi Dini dan Senam Nifas dengan Involusi Uteri." Jurnal Ilmiah Kebidanan Indonesia 7.04 (2017): 234-241.
18. Siregar SM. Karakteristik Ibu Bersalin dengan Sectio Caesarea di Rumah Sakit Umum Daerah Dr. Pirngadi Medan Tahun 2011-2012. Gizi, Kesehatan Reproduksi dan Epidemiologi. 2012;2(5). 